Mixed infection was detected in 3 patients of the first 5 years of life $(7.3 \%)$, the association was always rhinovirus in combination with MS virus or adenovirus, or parainfluenza virus. The disease was characterized by a more severe course, manifested by bronchitis, in 1 child of the first year of life with bronchial obstruction, in 1 of the patients-complicated by acute catarrhal otitis. Metapneumovirus infection was detected in all cases in the winter period, causing damage to the lower parts of the lungs with the development of acute bronchitis, obstructive bronchitis or pneumonia.

The main pathogens of obstructive bronchitis $(\mathrm{n}=5$; $12.2 \%)$ and tracheobronchitis $(\mathrm{n}=3 ; 7.3 \%)$ were of unknown etiology. Acute bronchitis was most often caused by a RSV infection ( $\mathrm{n}=3 ; 7.3 \%)$, metapneumovirus $(\mathrm{n}=2$; $4.9 \%$ ) and rhinovirus $(\mathrm{n}=2 ; 4.9 \%)$. In two cases acute bronchitis proceeded as a mixed infection: the association of RSV infection or rhinovirus and rhinovirus with adenovirus infection.

Winter seasonality of respiratory infections was prevailed $(n=19 ; 46.3 \%)$, children were less ill in spring $(n=11$; $26.8 \%)$, and rarely in summer and autumn $(n=6 ; 14.6 \%$, $\mathrm{n}=5 ; 12.2 \%$, respectively). In winter, viral pathogens were detected more often in patients - in $68.4 \%$ of cases $(n=13)$, including RSV virus $(n=6 ; 46.1 \%)$, rhinovirus $(n=4 ; 30.8 \%)$, metapneumovirus $(n=3 ; 23.1 \%)$ and mixed infection $(n=1$; 7.7\%). The spring-summer morbidity rate distinguished the group of children of the first year of life $(n=9 ; 69.2 \%)$.

There was no correlation between the type of pathogen and the age of the patients. Children over 5 years old were mostly ill with acute nasopharyngitis and tracheobronchitis $(n=6 ; 75 \%)$, whereas in patients of the first 5 years of life, acute respiratory infection often occurred in the form of lower respiratory tract lesions $(n=20 ; 60.1 \%)$. We had three infants aged 1-2 months in our study. The main disease was acute nasopharyngitis of undetected etiology ( $\mathrm{n}=2 ; 4.9 \%)$ and in one case caused by RSV infection ( $n=1 ; 7.7 \%)$. One child had a symptoms of acute bronchitis, the other - of obstructive bronchitis.

Among the established viral pathogens, rhinovirus was most often detected in children with symptoms of acute respiratory infection. The most severe course was associated with mixed infection, as well as metapneumovirus infection, mainly in children of the first 5 years of life and was accompanied by damage to the lower respiratory tract, including the addition of a bacterial infection.

\section{SOCIO-DEMOGRAPHIC AND FAMILY DETERMINANTS OF SCHOOL BULLYING AMONG YOUNG ADOLESCENTS}

LV Rychkova*, MA Petrash, AV Pogodina, TA Astakhova, Yu N Klimkina. Scientific Centre for Family Health and Human Reproduction Problems

\subsection{6/archdischild-2021-europaediatrics.467}

To determine socio-demographic and family determinants of school bullying among young adolescents.

Data for this study were collected during the 2017/2018 Health Behavior in School-aged Children (HBSC) survey on one of the Russian sites. The sample included 307 urban schoolchildren aged 11 years. We selected the questionnaires with the responses about school bullying. Demographic characteristics of families, outcomes and relationships in the families were analyzed as variables of interest.
293 questionnaires were selected (148 boys). All adolescents were divided into 3 groups depending on their replies about school bullying: group $1(\mathrm{n}=167)$ included adolescents, who had never faced bullying at school; group $2(n=90)$ included adolescents, who had faced bullying at school 1-2 times during last 2 month; group $3 \quad(n=36)$ had faced bullying several times per month and oftener.

It was shown that $10(6.1 \%)$ adolescents of the 1 st group, $14(15.9 \%)$ adolescents of the $2 \mathrm{~d}$ group and 7 (19.4\%) adolescents of the $3 \mathrm{~d}$ group did not hope for parents' help in solving school problems $(\mathrm{p} 1-2=0.023 ; \mathrm{p} 1-3=0.025)$. Twentyone $(13.2 \%)$ people in the 1 group, $21(23.9 \%)$ in the $2 \mathrm{~d}$ group and $10(27.7 \%)$ in the $3 \mathrm{~d}$ group were not sure their parents were willing to go to school to talk to teachers ( $\mathrm{p} 1-$ $2=0.033 ; \mathrm{p} 1-3=0.057) ; 10(6.2 \%)$ schoolers of the 1 st group, $16(18.4 \%)$ of the $2 \mathrm{~d}$ group and $7(19.4 \%)$ of the $3 \mathrm{~d}$ group believed that their parents were scarcely involved or not at all involved in their school life $(\mathrm{p} 1-2=0.006 ; \mathrm{p} 1-3=0.025)$. Adolescents, who had suffered from bullying, relied on parents' help in decision-making to a lesser extent ( $1-2=0.031 ; \mathrm{p} 1$ $3=0.052)$.

Eighty (90.9\%) adolescents from the $2 \mathrm{~d}$ group and 28 $(80 \%)$ from the $3 \mathrm{~d}$ group thought they looked 'normal' and 'good' in comparison with 162 (97.6\%) adolescents, who had never experienced school bullying (p1-2=0.038; p1-3<0.001). Moreover adolescents, who had suffered from bullying, had lower life satisfaction (p1-2<0.001; p1$3=0.002$ ).

The family composition, material well-being, occupation (employed/unemployed) did not show significant connections with school bullying of adolescents.

Young adolescents, suffering from school bullying, do not feel they get adequate support from their parents. As a result they have low self-esteem and low life satisfaction.

Therefore, work of a teacher and a psychologist with adolescents, suffering from school bullying, should be aimed at not only normalizing the situation at school, but also at determination and correction of imbalanced relationships in the family.

\section{THE USAGE OF LEAN (SIMULATION) TECHNOLOGIES' TOOLS TO EVALUATE NUTRITION STATUS AND PHYSICAL DEVELOPMENT IN PEDIATRICS}

VP Novikova*, IM Zhugel, SA Chuinyshena, OA Luzanova, OV Lisovskii, AV Gostimskii, IA Lisitsa, IV Karpatskii, MV Gavschuk, NV Getsko, EO Lisovskaya, MD Prudnikova, AN Zavyalova. St.Petersburg State Pediatric Medical University, Ministry of Healthcare of the Russian Federation, Saint Petersburg, Russia

\subsection{6/archdischild-2021-europaediatrics.468}

To work out the skill of assessing physical development and nutritional status of children and adolescents in various ways, to carry out comparative analysis of methods.

Questionnaire data of patients examined in the office of a doctor - a nutritionist with various disorders of nutritive status - 101 people.

Anthropometry was performed, physical development was evaluated by the WHO Anthro program, using centyl tables, and the impedance method (body composition). Statistical analysis, which included parametric statistics methods as well as r-Spearman rank correlation, was performed using Statistics 23.1 software. 